\title{
Interethnic Tolerance of Chukchi
}

\author{
Aida Egorova, Tuiaara Sidorova, and Valentina Davydova
}

\begin{abstract}
The article presents the results of scientific expedition studying the level of interethnic tolerance of representatives of Chukchi ethnos who live in the Republic of Sakha (Yakutia) (2012). In the process of empirical study it was found that representatives of Chukchi ethnos have a prevailing average level of ethnic tolerance.
\end{abstract}

Index Terms-Chukchi, ethnical tolerance, indigenous peoples.

\section{INTRODUCTION}

The study of interrelation between the unique culture of peoples of the North and psychology is aimed at connecting history with routine way of life, ethnical specificity with its modern interpretation. The study of cultural and specific mechanisms of ethno psychological display of personality of native people will allow, with taking into consideration size and variations of the culture standard, to render effective and categorical psychological assistance that makes it possible to establish really harmonic relations with own personality and the world around.

Revival and maintenance of ethnic identity and ethnic self-consciousness of indigenous peoples is an important task of the modern society. In connection therewith, studies of ethnic identity and interethnic tolerance specificity of peoples living in Northeastern Russia, are of special topicality.

The Sakha Republic (Yakutia) is a multinational region, where historically not only native ethic groups, but also representatives of different peoples of Russia and CIS countries have lived.

On the territory of the Sakha Republic (Yakutia) 32,860 representatives of low-numbered peoples of the North, including the Evenks-18,232, the Evens-11,657, the Yukaghir-1,097, the Chukchis-602, the Dolgans-1,272 live. Population of the low-numbered peoples of the North is $3.2 \%$ within all population of the Sakha Republic.

The native low-numbered peoples of the North, settled dispersed on a huge area of Arctic space, were formed as an ethnos exactly on this territory. During centuries they have leaded a specific nomadic and semi-nomadic life, which turned into their way of life. These peoples possess original ancient cultures; their life is inseparably associated with native lands and traditions. Ensuring their legal protection, improvement of social and economic

Manuscript received March 4, 2013; revised May 20, 2013. This work was supported in part by the Sakha Republic Department of Nations under Grant GZ-1174 of 06.09.11.

A. Egorova, T. Sidorova, and V. Davydova are with the North-Eastern Federal University Institute of Psychology, Yakutsk, 677008 Russian Federation (e-mail: aidaego@mail.ru, tuyas_ok@yahoo.com, dvy18@mail.ru). status is considered as matter of priority of a state policy of the Sakha Republic (Yakutia).

The Chukchi - the most ancient inhabitants of continental regions of the far north-east of Siberia, mediums of an inland culture of wild deer hunters and fishermen. Neolithic findings on the Ekytikyveem and Enmyveem Rivers and Lake Elgytg date back the second millennium B.C. By the first millennium C.E., having domestic deer and partially leading sedentary life on a sea shore, the Chukchi came into a contact with the Eskimo. A transfer to the sedentism was especially active in the XIV-XVI centuries after penetration of the Yukaghirs in the Kolyma and Anadyr valleys, who occupied places of wild deer open seasons. The Eskimo population of coasts of the Pacific and Arctic Oceans was partially forced out in other coastal regions by the continental hunters-Chukchi, and partially assimilated. In the XIV-XV centuries as a result of the penetration of the Yukaghirs in the Anadyr valley a territorial separation of the Chukchi from the Koryaks happened, connected with the last by origin.

In the epoch of global profound changes of societies, not only social and economic aspects of development, but also fates of many native peoples, whose historically formed way of life being based on a traditional culture, undergoes a significant influence of an industrial civilization, are intertwined. A problem of adaptation of the native peoples to changes of natural environment, social and technical transformations undoubtedly is of a research interest. On the other hand, the native peoples have new ways to solve problems, connected with an opportunity to use innovative technologies in all spheres of life that will promote preservation and development of a native language, the origin culture, spiritual heritage of the people.

Processes of a cross-cultural assimilation and an interethnic cooperation long ago became relies of the modern society, in the period of global changes, these processes require special attention. Decreases of an interethnic tension, increase of a cross-cultural tolerance, development of integration processes are urgent today. A research of contents of ethic stereotypes, peculiarities of the interethnic cooperation and socio-cultural adaptation of the low-numbered peoples is of the great interest.

\section{LITERATURE REVIEW}

There are some descriptions of the Chukchi national character in a historical and ethnographic literature: "Main psychic traits of the Chukchi - extremely light excitatory tendency, reaching ecstasy, a tendency to murders and suicides under any reason, love of independence, persistence in fights; at the same time the Chukchi are hospitable, usually good-natured and eager to help their neighbors, even Russian ones, during starvations"[1]. Physical strength, endurance, 
persistence to natural forces, diligence, working capacity, hot blood, invincibility, obstinacy, compassion, hospitability etc. are among outstanding characteristics of the Chukchi ethnos.

Severe climatic and natural conditions form such character traits of the Chukchi as endurance, ability to survive and adaptivity in difficult conditions of existence, ability to overcome a hardship. "The Chukchi is very resistant to cold, hunger and other hardships"[2]. "The wild deer hunters usually go hunting with a little food reserve with an eye to a bag"[2]. These character traits belong not only to men, but also to women. "The deer shepherds, men and women, frequently spend 2-3 days sleepless. A young girl, having worked on fells during the whole day, then watches a herd all night long, and in the morning, coming back home, again sets about work and works up to the evening without any sights of fatigue" [2].

A peculiarity of the Chukchi is unity with the nature, the Chukchi from ancient time were conquerors of the nature, tried to extract all the goods from it to survive. Ethnographers note observance, headpiece and quick wit of the Chukchi in private life. The Chukchi are remarkable for their physical strength; they are notable for special adroitness and strength on traditional types of activity.

In historical past of the Chukchi there were invasive wars with neighboring tribes and confrontation with the Russians. Bellicosity, aggression, fearless was typical for the Chukchi. "The Chukchis' successes in their confrontations with their neighbors to some extent were due to their armament and warrior training. The warrior was each man, young man, capable to use weapons and drive a deer team. Constant trainings of young men and teens developed fearlessness, endurance, strength, adroitness, skill to use weapons, reflexes and other qualities necessary for warriors and hunters" [3].

"The Chukchi all are courageous, fighting with pikes, and quick to shoot bows, sudden to ride deer, in talks quick to answer... have a custom: getting up, everybody goes to a deer herd, and coming back, fights with each other with pikes and, putting on kuayks, runs round, for example, during three and more hours, and then shoots each other bows. When they nomadise, go after the herd always on foot in kuyaks" [4]. "Young men frequently exercise in armature wearing, putting them on for a day, following sledge trains along side mountain roads. Frequently they are to carry some loads on themselves" [5].

Soreness, hot blood and invincibility are among emotional qualities. There were two opposite visions of hot blood of the Chukchi. An inscription on a map dated on 1765 says: "The Chukchi - the cruelest and bellicose nation, hostile to the Russians. They killed themselves, being taken captive" [2]. According to Maydell, Nordenskiöld et al.: "The Chukchi-peaceful and harmless" [2]. "Former invincibility still remains, especially among the deer Chukchi. It manifests itself in small things of everyday life. The Chukcha is easily irritated. A trifle is enough to make him angry. The Chukcha in anger growls, shows ivories, bites his sleeves or knife handle, in this way dares to fight. Some Chukchi even cry for anger and tear hair as capricious children" [2].

Obstinacy and quick wit, even in trifles, are noted as outstanding characteristics: "Besides their hot blood, the Chukchi show special obstinacy in relations to things and actions, being to them of a temporal interest" [2].

With that, the Chukchi are noted for simplicity, compassion, hospitability. "Compassion is typical for the Chukchi"[2]. "Hospitability is more developed among the costal Chukchi, then deer ones. They are much more superstitious in relations to "protection from diseases"[2]. The Chukchi say that even if a guest beats a lord, the lord has to stay friendly to him"[2].

Community relations, based on blood-sibling connections, the nomadism form collectivist values, mutual supportiveness, group cohesion. The Chukchi call themselves "real people", their language-"real language", their home-"real home". All that refers to another tribe, they have put on the same level with evil spirits [2].

Theoretical aspects of studying ethnical identity are presented in the works of G. Starovoytova [6], V. Tishkov [7], T. Stephanenko [8], A. Okoneshnikova [9], etc.

In ethnographic works it is mentioned that indigenous peoples' representatives are notable for discipline, staying power, strong will, tendency to self-control, ability to be responsible and careful, hard-working, tolerant and nature considerate, because such features has enabled their ancestors to survive in severe climatic conditions. Hospitality, generosity, love of children, sensitivity to jokes and humor are the characteristics of a Northman.

In ancestral relations, representatives of smaller peoples show feeling of solidarity, team spirit, patriotism, respect popular traditions. It is difficult for them to adapt in strange lands, they feel homesick, and most of them are introverts as though quite friendly and open in communication with close people and foreigners.

In cross-cultural works, existence of peculiar ideas of soul is mentioned. Not only a person, but animals and plants have the soul (uvirit). Plants' soul is small. A person, except for one soul knowing a body (uvik), has some more partial souls, they are special "souls of body organs", feet and hands. These souls may be casually lost, and then respective member becomes ill, or even dry off [10]. Chukchi believed in different spirits. Spirit owner, spirit defender, sea spirit were considered by Chukchi as the kind spirits. The evil spirits were kelet, earth spirits, spirit of infectious diseases, spirit of syphilis, spirit of colic, spirit of cannibals, etc.

A special role in formation of the personality's picture of the world of the "small" peoples is allocated for studying of irrational ways of world-view, non-reflexive forms of knowledge. As studies of A. Menyashev [11] and S. Semenova [12] showed, existence of mythological essence in the structure of consciousness of native people from the North appears through the ways of interaction with natural and social environment. According to A. Menyashev who has conducted research in the group of Nivkhs, there are two opposite tendencies fixed in the development of mythological consciousness of these peoples' representatives. The first tendency, so-called stabilization, is aimed at adaptation of the ethnos to natural and social conditions in change. The second one is called by the researcher as demythologization process, which is understood as gradual loss of mythological essence due to formation of scientific and philosophical ideas of the world. In the study, the author comes to a conclusion that at present there is, on the one hand, a loss of national 
psychological features, and on the other hand, - acceptance and formation of new psychological qualities [7].

G.N. Kriger, who conducted a study of Teleuts, has found the positive attitude to own ethnic origin, closeness of autoand hetero stereotypes [13].

When studying psychological features of representatives of native peoples of Kamchatka (Itelmens, Koryaks, Chukchi, Evens), A.A. Buchek revealed high extent of cross-cultural mutual understanding between the peoples occupying Kamchatka [10]. Reservedness, reticence, moderateness and briefness of the North's person were called peculiar psychological features of the North people, however, along with sociability, openness, affability, friendliness, cheerfulness, and also attentiveness to interlocutors, readiness to help, goodwill and hospitality [14].

The "native person of Kamchatka" auto stereotype was described as honest, benevolent, easily trusting to another, open for communication, sincere, friendly, always ready to help another, such person is patient, hardworking and persistent in achievement of his objectives, knows and understands the nature around well, observant. He is always quiet, counterbalanced, modest, laconic, with a manner to speak slowly, having special "silence in soul" [10].

In hereto' stereotypes of Kamchatka young people, among qualities which are characteristic of indigenous people of Kamchatka, deservedness, reticence, moderateness and briefness of the North's person were called peculiar psychological features of the North people, however, along with sociability, openness, affability, friendliness, cheerfulness, and also attentiveness to interlocutors, readiness to help, goodwill and hospitality [15]. Despite an inconsistent image, a rather high degree of coherence of expectations in relation to the group of native peoples should be noted. Besides, quite interested is a measure of coherence of autoand heterostereotypes: many characteristics repeat each other in self-descriptions of native peoples of Kamchatka that may be considered as an indicator of high-leveled cross-cultural mutual understanding between the peoples occupying Kamchatka [15].

Studying a level of ethnic tolerance of Chukchi, living in the territory of the Republic of Sakha (Yakutia) was the purpose of our study.

Chukchi living in Kolymskoye village of the Nizhnekolymsky region were the object of the study. Kolymskoye village is the only place of compact accommodation of Chukchi in the Republic of Sakha (Yakutia), inhabitants of which are engaged in mainly traditional economic sectors (reindeer breeding, fishery and hunting) and united in "Turvaurgin" tribal community. In total, 60 people (30 men and 30 women) were studied, young Chukchi representing two age groups (from 18 to 35 years old), and mature Chukchi (persons over 35 years old).

Specifics of an ethnic originality of inhabitants of the village: most of representatives of the indigenous peoples are descendants of interethnic marriages, many of them have Chukchi, Evens, Yukaghirs, Yakuts, and Russians in their families. Difficult historical development, assimilatory processes, loss of the native language affected originality of Chukchi' interethnic contacts.

\section{METHODS}

To study a level of ethnic tolerance the "Tolerance index" questionnaire made by G. Soldatova, et al., revealing a level of tolerance and an intolerance of person was used. Results on a scale "Ethnic tolerance", reflecting the level of ethnic tolerance-intolerance (the attitude towards people of other race and ethnic group, to own ethnic group, assessment of cultural distance) are included in the analysis of this article. This scale consists of 7 questions; on each the respondents shall give 6 versions of answers. Points are appropriated to each version of the answer: I absolutely not agree - 1, I don't agree -2 , I rather don't agree - 3, I rather agree - 4, I Agree 5 , I Completely agree -6 . Level of ethnic tolerance on a scale was determined as follows: from 7 to 19 points - low, from 20 to 32 points - average, from 33 to 42 points - high levels. When processing results of a methodology $\varphi$-criterion was used, that is, Fischer's angular transformation.

\section{DISCUSSION}

The majority of Chukchi doesn't pay attention to the ethnic origin of person in communication and have international aims. In comparison with ethnic identity, all-civil (all-Russian) identity is the most significant for Chukchi. As a whole, the average level of ethnic factors importance in Chukchi' life with a tendency to decrease is noted.

As a whole, according to the selection of Chukchi on a "Ethnic tolerance" scale of "Tolerance index" questionnaire, the average level is found in all the groups (Table I).

TABLE I: THE TOLERANCE INDEX (AVERAGE VALUES)

\begin{tabular}{lll}
\hline \hline Scales & $\begin{array}{l}\text { Ethnic tolerance } \\
\text { scale }\end{array}$ & Tolerance level \\
Men from 18 to 35 & 21.2 & average \\
Men over 35 & 22.1 & average \\
Women from 18 to 35 & 23.5 & average \\
Women over 35 & 25 & average \\
All & 22.9 & average \\
\hline \hline
\end{tabular}

The analysis of certain questions on a scale "Ethnic tolerance" showed that as a whole the majority of examinees show ethnic tolerance. $52 \%$ of examinees don't agree that mixed marriages are usually more problem, than marriages between people of the same nationality, 38\% don't agree that is normally to assume that your peoples are better, than all the others, $31 \%$ don't agree that is difficult to treat some nations and peoples kindly, $38 \%$ are ready to accept the person of any nationality as the member of their family, $45 \%$ agree to have people of different nationalities among their friends, $31 \%$ can imagine a black person as their close friend.

When processing results of a methodology $\varphi$-criterion was used, that is, Fischer's angular transformation. As a whole, by using this methodology statistically significant distinctions were found between men and women ( $\varphi$ emp $=2,226$ at $p \leq 0.05$ ); between Chukchi of young and mature age statistically significant distinctions were not revealed (

Statistically significant gender distinctions are found on questions: No. 4 " Caucasians will be treated better, if they change their behavior", where women rather disagreed ( $\varphi$ emp $=1,856$, at $p \leq 0,05)$, No. 7 "It is normally to consider that your people are better, than all the others", where women 
rather disagreed ( $\varphi$ emp $p=4,395$ at $p \leq 0.01)$, No. 11 "I am ready to accept person of any nationality as the member of my family", where women agreed ( 14 "I want to have people of different nationalities as my friends", where women agreed too $(\varphi е m p=3.070$, at $p \leq 0.01)$, No. 21 "I can imagine a black person as my close friend" where women rather agreed ( $\varphi е m p=2.142$, at $p \leq 0.05$ ). Thus, on certain questions women showed higher level of ethnic tolerance, than men.

\section{CONCLUSION}

Thus, as a whole on Chukchi selection, the level of ethnic tolerance is average. As for hetero stereotypes of representatives of Chukchi ethnos, among positive features prevail: endurance, hospitality, good nature, sense of duty, love of children, love to native places, modesty, diligence, ability to survive in severe conditions, and among the negative ones are aggression, talkativeness, suggestibility, arrogance, trustfulness, inertness, non-obligatoriness, absence of purposefulness, tendency to abuse of alcoholic drinks, frankness, indifference, deservedness, weakness for temptations, weak character, shyness, obstinacy, loss of national dignity, feeling of national lameness.

\section{REFERENCES}

[1] Brockhaus and Efron, Encyclopedic Dictionary, S-Pt. Brockhaus-Efron, 1890-1907.

[2] V. G B. Tan, Chukchi, Leningrad, 1934, ch. 1, pp. 8-28.

[3] Istoriya $i$ kultura chukchej. Istoriko-etnographicheskie ocherki, [History and culture of the Chukchi. historical and ethnographic essays], Ed. Krushanov A. I., Leningrad, 1987, pp. 105.

[4] The Central State Archive of the Far East RSFSR, f. 702, op. 1, d. 313, 1. $34 \mathrm{ob}$.

[5] Archive of Leningrad Part of the Institute of Anthropology and Ethnography of the AS SSR, col. 3, op. 1, pp. 2, 33.

[6] G. V. Starovojtova, $K$ issledovaniju etnopsikhologii gorodskikh zhitelej, [To Study of Ethnopsychology of City Dwellers], Sovetskaya ehtnografiya, [Soviet ethnography], vol. 3, pp. 45, 1976.

[7] V. A. Tishkov, Rekviem po ehtnosu. Issledovaniya po socialno-kulturnoj antropologii, [Requiem for Ethnos. Researches on Welfare Anthropology], Moscow, 2003.

[8] Transformacija identifikacionnykh struktur v sovremennoj Rossii, [Transformation of Identification Structures in Modern Russia], ed. T.G. Stefanenko, Moscow, 2001.

[9] A. P. Okoneshnikova, Mezhehtnicheskoe vospriyatie i ponimanie ljudmi drug druga, [Interethnic Perception and Understanding between People], Dr. of Psychol. dissertation, Moscow State Univ., 1989.

[10] A. A. Butchek, Psikhologicheskij portret korennogo zhitelja pripoljarnykh territorij (na primere korennykh narodov Kamchatki), [Psychological Portrait of Native Inhabitant of Polar Area], Petropavlovsk-Kamchatsky: Pub. KSPU, 2004, pp. 173.

[11] A. E. Menyashev, "Mifologicheskoe v strukture ehtnicheskogo soznanija korennykh narodov o. Sakhalin" ["Mythological in structure of ethnic consciousness of indigenous people of Sakhalin"], Ph.D. dissertation, Dept.Psychol, Khabarovsk. Univ., Russian Federation, 2005.
[12] S. V. Semenova, "Osobennosti mifologicheskogo samosoznaniya korennykh narodov Kamchatki" ["Features of mythological consciousness of indigenous people of Kamchatka"], Ph.D. dissertation, Dept. Psychol., Kamchatsky. Univ., Russian Federation, 2006.

[13] G. N. Kriger "Osobennosti strukturno-soderzhatelnykh kharakteristik ehtnicheskogo samosoznanija korennykh malochislennykh narodov Sibiri (na primere teleutskogo ehtnosa)" ["Peculiarities of structural and substantive features of ethnic self-consciousness of Siberia smaller peoples, by example of Teleut ethnos"], Ph.D. dissertation, Dept. Psychol., Kemerov. Univ., Russian Federation, 2005.

[14] I. S. Vdovin, Ocherki istorii i ehtnografii chukchej, [Essays of Chukchi History and Ethnography], Moscow, 1965.

[15] V. G. B. Tan, Chukchi, Leningrad, 1939, ch. 2, pp. 42.

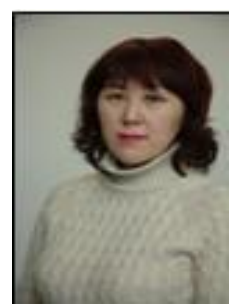

Aida Egorova is a PhD in Psychology, and associate professor. She is the head of social and ethnic psychology department of North-Eastern Federal University. Dr. Egorova was born on 29 May 1965 in Sakha (Yakutia) Republic. She graduated from the Moskow State Pedagogical Institute in 1988. She has been working at the North-Eastern Federal university for 23 years. She defended her thesis on specialty Social Psychology in Irkutsk in 1997. Dr. Egorova was awarded the title of associate professor of psychology at the Ministry of Education of Russian Federation in 2003. She became the head of Department of Social and ethnic psychology in 2002.

Her research areas include cross-cultural, ethnic and gender psychology. She has 76 publications, including 63 scientific and 13 educational works; she is the editor of 10 collections of scientific works. She investigates the Gender stereotypes of Sakha and indigenous nations of Yakutia).

Dr. Egorova is a member of International Association for Cross-Cultural Psychology.

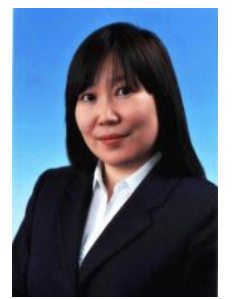

Tuiaara Sidorova is a senior lecturer of social and ethnic psychological department of North-Eastern Federal University. T. Sidorova was born on 19.10.1975 in Sakha (Yakutia) Republic of Russian Federation. She graduated from the Russian State Pedagogical University in 1997. She has been working at the North-Eastern Federal University for 8 years.

Her research areas are psychology of innovation, motivation, social and ethnic psychology. She has 19 publications. Ms Sidorova is a member of the Russian Psychological Society.

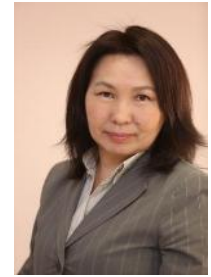

Valentina Davydova is a senior lecturer of social and ethnic psychological department of North-Eastern Federal University. Davydova V. was born in Republic of Sakha (Yakutia) in 18 October 1961. In 1983 graduated from the Yakut State University. Fields of study: social and ethnic psychology and social work. She worked as a teacher in a secondary school. Now she is a Senior Lecturer of Social and Ethnic Psychological Department of the North-Eastern Federal University named after M.K. Ammosov. She has 47 publications, including 30 scientific and 17 educational works.

Ms. Davydova is a member of the Russian Psychological Society, and Russian Political Science Association. 